\title{
GEOGRAPHICAL IMAGE OF THE WORLD IN THE LONDON PSALTER MAPS FROM THE $13^{\text {TH }}$ CENTURY
}

\author{
Mirko Grčićk1 \\ * University of Belgrade - Faculty of Geography, Belgrade
}

\begin{abstract}
The subjects of this paper are two maps from the $13^{\text {th }}$ century Psalter, found in London. These are the Psalter World Map and the Psalter List Map. Both maps are designed in the shape of a circular disk, modeled on medieval mappae mundi T-O type. The first is a pictorial map, the second is descriptive. The primary goal of these maps was not to objectively present geographical reality, but to express biblical symbolism and medieval Christian cosmology and thus serve as a reminder in devotional practice. By their deconstruction, we discover not only the religious Christian view of the world, but also the historical and cultural representations of medieval people projected on a geographical basis. Maps from the London Psalter have so far been viewed more as a "religious document" than as an objective "geographical image" and a "historical document". Therefore, they were rarely used as a historicalgeographical source. The aim of this paper is to deconstruct the text and context of the mentioned two maps and thus interpret their imaginative geography and geographical representations, the meaning of symbols and toponyms, which may be of interest to researchers dealing not only with historical cartography but also with historical and human geography.
\end{abstract}

Keywords: Psalter World Map, Psalter List Map, Medieval mappae mundi, T-O maps, geography, Medieval cartography, toponyms.

1 Corresponding author: Prof. dr Mirko Grčić, Univestiy of Belgrade - Faculty of Geography, Belgrade; e-mail: mirko@gef.bg.ac.rs 


\section{Introduction}

In the London Psalter, or book of psalms from the $13^{\text {th }}$ century, there are two unusual maps of the Old World on the obverse and reverse of the same paper. They are called the Psalter World Map and the Psalter List Map. Both maps are designed in the shape of a circular disk, modeled on medieval mappae mundi. This type of map was made mainly by monks in the monasteries of Western Christianity between the $5^{\text {th }}$ and $15^{\text {th }}$ century, called "monastery maps", "monastic maps" or "radkarte" in German. They had a round or oval shape in the form of the letter $\mathrm{O}$ inscribed with $\mathrm{T}$ (T-O type maps), in different variants (Uhden, 1931; Destombes, 1964). T-O maps originate from the ancient conception of the Earth's sphericity and zonal belts - climates (Talbert and Unger, 2008). The prototype of this type of map is the Picture of the World from the "Etymology" of St. Isidore of Seville from 623. Related to this is the Salusta map model. O - represents the world's ocean that surrounds the land, and $\mathrm{T}$ - the inland waters that divide the land circle in three continents of the Old World - Asia, Europe and Africa - one for each of the three sons of Noah. Such maps did not have a grid, scale, and conventional legend (Woodward, 1987; Рајт, 1988; Орачев, 2005; Rana, 2008; Burke, 2016).

Woodward noted that maps of the mappae mundi type represent "history projected on a geographical basis" (Woodward, 1987). However, the geographical image of the world on medieval monastery maps had a multifaceted polyvalent context - cognitive, ideological, religious. The geographical representations of Europeans about distant oriental countries whose protagonists were crusaders are far more polyvalent than those usually created in Arabic or Chinese cartography. They speak the language of symbols not only about the real features of geographical space, but also about historical and imaginary events and characters, cultural phenomena, mythical legends and biblical stories, so it can be said that these maps represent a "projection of culture on a geographical basis" (Šakaja, 2015). To this we can add a projection of mythological and religious representations, since such maps usually served the needs of pilgrimages or as a reminder in devotional practice.

For world maps of this type, narrative is key. Their primary goal was not to accurately portray geographical reality, but to spatially express biblical symbolism. They are more a narrative than a mirror of reality, more a cartographic illusion than an objective perception of geographical space. Medieval cartographers used imaginative picture drawings to depict distant worlds surrounding European Christian civilization from the North, South 
and East, even more stranger and unnatural than they actually were (Klein, 2016; Foys and Heather, 2018).

The Psalter World Map is a kind of pictorial mappae mundi of the Ebstorf-Hereford type. It was named after the Psalter of London (a book of prayers with psalms) in which it was found as an illustration (Morgan, 1988). On the reverse is the Psalter List Map. In the calendar of the Psalter, April $3^{\text {rd }}$ is marked as a holiday in honor of St. Richard of Chichester (died 1253), who was canonized in 1262, which means that the Psalter was created after that date. It is kept in the British Library in London (British Library Add. MS. 28681, fol. 9r and fol. 9v).

The dimensions of the Psalter are $17 \times 12.5 \mathrm{~cm}$, the paintings on parchment $10 \times 15 \mathrm{~cm}$, and the diameter of the circle with the world map is about $8.5 \mathrm{~cm}$. The Psalter World Map, although small in size, contains an unusually large number of details and 91 geographical names of places. The map was probably created on the basis of a larger map, which was given to King Henry III around 1230 and placed in the painted hall of the Palace of Westminster, which burned down in a fire in 1263 (Barber, 2013). However, the description of Matthew Paris's Westminster map (Matthew Paris's, c. 1200-1259) suggests that this map was based on the Macrobius map model. The visual emphasis on France and Paris on the Psalter World Map indicates that its model was a French map (Van Duzer, 2019).

Based on Ven's comparative diagrams showing the overlap of toponyms between the Psalter World Map and the work "Descriptio mappe mundi" by Hugh of St. Victor (Hugh of St. Victor, c. 1096-1141), it was determined that there is a $69 \%$ overlap, while there is a $76 \%$ overlap between the Psalter List Map and the mentioned work "Descriptio" (Wacha and Levernier, 2019). On the Psalter List Map, the distribution of cities by provinces is completely different, and there is no support in the part "Descriptio", although there is a high degree of overlap of toponyms. Based on that "it seems that the Psalter List Map on the reverse is a copy of an older map" (Schöller, 2014). The Psalter also contains other illustrations, including enlarged pictorial initials denoting the main parts of the text (Büttner, 2004; Brot, 2018).

The Psalter World Map is rarely used as a historical source, because its perception of objective geographical space is small compared to academic cartography. Harley believes that maps of the mappae mundi type could play a greater role in the practice of historical geography, if they were treated as text. Their "deconstruction paves the way for the reintegration of cartography as a work of historical and human geography" (Harley, 1989). 


\section{Iconography and symbolism of the Psalter World Map}

Regarding the Psalter World Map the Psalter List Map, Brot asked some important questions: What is the function of these maps in the Psalter? Why are these maps included in the book of Psalms? What are the possible connections between the maps and the text in the Psalter? (Brott, 2018).

The main function of the mentioned maps in the London Psalter is to use the cartographic image of the world and the illustration of biblical representations to serve for the interaction between the object and the observer during devotional practice (La Porte, 2012). The Psalter World Map presents medieval semi-mythical geography, which places the real world in the context of faith in salvation (Reudenbach, 1998). Long before the modern concept of the East, shadows of Christian notions emerged on the eastern horizon, woven into the early medieval imagination. It is not only a geographical but also a spiritual map, designed to help the observer during prayer as a reminder and alternative guide to an alternative pilgrimage. It intertwines notions of the material world with theological notions of the spiritual world (Wacha \& Brott, 2020).

The Psalter World Map is actually a three-part image, which shows the whole universe in the spirit of Christian cosmology and eschatology - the kingdom of heaven and the kingdom of Earth, a universe in which divine apparition, nature, man and his creations, mythical and real, superhuman and human. In the upper part is an illustration of Christ's presence in the cosmos, in accordance with the Christian prayer recorded in the Bible: "Our Father, who art in heaven, Hallowed be thy name; Thy kingdom come, Thy will be done in earth, as it is in heaven" (Matthew 6: 9-13; Luke 11: 2-4). God the Savior Jesus Christ appears on the starry sky as a judge, with the cross sign on the halo of holiness, in a robe in the royal burgundy color with a white hem and in a shirt of precious lapis lazuli color. With his right hand raised with two outstretched fingers, he seems to be blessing, which symbolizes salvation. Two winged angels swinging a thurible, for the purpose of cleansing the sacred space, which symbolizes the kingdom of heaven. With his left hand, Jesus holds a small T-O globe as a Pantocrator (Almighty). The image of Christ Pantocrator was popular in Byzantine art. In Western Christianity, it is mostly associated with the scene of the Last Judgment (Woodward, 1987; Barber, 2013).

The middle part of the painting on the body of Christ is dominated by a round map of the earthly sphere which "transforms a schematic circular 
disk into a visual encyclopedia" (Barber, 1989). The places of Christ's earthly mission are marked on the map, which will later become the focal points of the pilgrimage. Jerusalem in the center of the earthly disk and the small solar disk east of paradise, suggest a geocentric view of the world, as well as many words and sentences in the Psalms. The words Earth (terra) and World (orbis terra) are repeated in the Psalter 168 times (Brott, 2018). The round map model centered in Jerusalem is an illustration of the divine plan for the creation of the world (Bagrow, 1966). Jerusalem as the geographical and spiritual center of the world, in accordance with the Holy Scriptures, creates the so-called "omphalos syndrome" (Gr. omphalos - navel, center) and suggests where the creation of the world began (Whittington, 2014). "Positioning Jerusalem at the center of the map becomes a feature of world maps after 1120 as a consequence of the crusader mentality" (Barber, 2013). Around it is the Holy Land with places related to the life and suffering of Jesus Christ. The Holy Land is hypertrophied in relation to other regions, in accordance with its importance in Christianity. In the Far East is the Garden of Eden, with Adam, Eve and the tree. In the northeast, there is a fenced and isolated landscape of evil Gogs and Magogs. In the unknown peripheral areas in the south, mythical visions of grotesque and monstrous characters of evil people and animals are distorted, which instilled fear of the uncivilized and non-Christian world. These scenes represent segments of complex Christian mythology (Strickland, 2003; Van Duzer, 2013).

The map is dominated by circular shapes (a disk-shaped Earth with the center in Jerusalem, a circular world ocean, an atmospheric envelope with wind figures, semicircular directions of mountain ranges and rivers), which indicate the circular organization of geographical space, the perfection of God's creation. Medieval people knew that the Earth had the shape of a sphere, but they still represented it as a disk. It is interesting that on the eastern edge (above) of the Psalter Map is the text Col[um]ne [H]erculis, and on the western edge (below) is a drawing of the Pillars of Hercules, which means that they knew that the Earth was round, but they mistakenly believed that East and West meet on the world's oceans behind the Pillars of Hercules (today's Gibraltar).

On the outer edge of the map, the figures of 12 windmills with the names of the winds are presented:

Subsolanus - eastern; Ve[n] tus Eurus - east-southeast; Ventus Euronothus - south-southeast; Anster vel Nothus - southern; Libonothus - south-southwest; Ve[n]t[us] Aufricin[us] - west-southwest; Ventus Zaphirus - western; Vent[us] 
Corus - northwest; Ve[n]t[us] Circi[us] - north-northwest; Ve[n]tus Septe[n] trion [alis] - northern; Aquilo - northeast; Ve[n]t [us] Wultur[us] - east-northeast wind (Milller, 1895; Whittington, 2004).

The ocean as a water zone surrounds the terrestrial world. The ocean and the Mediterranean Sea are colored green, the Red Sea red, and the rivers blue. On the Red Sea, the passage of Moses is marked, through which, according to the biblical legend, the Israelites came out of Egypt.

Some important imperial cities are marked with a symbol in the form of a crown - Rome, Constantinople, Alexandria, Carthage. The goldenyellow triangular symbols represent cities and places that are relevant for that time, such as the birthplace of Alexander the Great in Macedonia. Some places related to Christ's life on Earth are also marked in Galilee: Bethlehem - Christ's birthplace, Nazareth - where he grew up, Jericho and the Knights or Bethsaida - where he healed blind people, Capernaum and the Sea of Galilee - where he performed miracles, Jerusalem - where he was crucified and resurrected.

A larger number of places on the Psalter World Map and Psalter List Map are directly related to the texts of the Bible than to the psalms themselves, although both are intended to illustrate and clarify the texts of the psalms. Of the 36 geographical names listed or repeated in the text of the psalm, seven are located on the Psalter World Map: Jerusalem, Babylon, Mount Zion, Egypt, and Ethiopia. Lebanon is mentioned six times in the Psalms and marked on the map as a mountain. The Jordan River is mentioned three times. Egypt is shown along the Red Sea, including the narrow passage of Moses (Brott, 2018).

The lower part of the painting presents an underground world dominated by two conflicting two-legged feathered dragons, as symbols of trickery and hatred. They are the antipodes of the two angels in heaven.

On the Psalter World Map, there is a three-part structure of geospace in terms of civilization. Similar to ancient Greece and Rome, there are areas where "we, the civilized" Christian people live, centered in Jerusalem, "barbarians" in the enclosure of Gog and Magog in the northeast, and "monsters" living in a distant unknown country in the south of ecumene. According to one hypothesis, the monsters represent the unknown inhabitants of central Africa in the legendary (fictional) Christian kingdom of Presbyterian John. According to the second hypothesis, these are different creations of God, which have been moved here from God's world. "This realm is of great 
Geographical image of the world in the London psalter maps from the $13^{\text {th }}$ century

interest to the monastic public, where creatures represent the sinful nature of man and act as material visualizations or manifestations of deviant behavior" (Strickland, 2003). According to the third hypothesis, it is a cartographic representation of the "anti-ecumenical" or "southern continent". The Roman Neoplatonist from the $5^{\text {th }}$ century, Ambrose Theodosius Macrobia, in his work "Comments on Scipio's Dream" (Comentarii in somnium Scipionis 2, 9), believes that the ecumenism is separated by an ocean from the unknown anti-ecumenism where the "Antipodes" live. It is the notions of monster races, as the Antipodes of "normal", "superior" people of the Christian world, that are "embedded in the geographical imaginations of medieval mappae mundi" and placed on the margins of maps (Šakaja, 2015, 279-280).

Thus, the Psalter World Map symbolically accumulates and merges religious, mythical, historical and geographical contents. At the same time, the contents are asynchronous, often over a long period of time, ranging from biblical and ancient times to the middle of the 13th century, when this map was created. The real spatial proportions are disturbed on it, the contours of the land and the sea are completely deformed due to the adjustment of the drawings. The Psalter map shows a synchronic-diachronic and realimaginative mosaic in which there are places that evoke narratives from the Bible (Noah's Ark on Mount Ararat, Garden of Eden in the East, Paradise Rivers), from Greek mythology (Pillars of Hercules, Amazons, Troy), New Testament (places of Christ's earthly mission) and from European cultural and political history (Rome, Constantinople). In that way, time and space are relativized and merged into one imaginary asynchronous-holistic picture of the world.

\section{Analysis of geographical contents of the Psalter World Map}

\section{Geographical contents in Asia}

The geographical horizon of Europeans in the Middle Ages did not reach far beyond the former empire of Alexander the Great. The attitude of Europeans towards the Asian geographical area was complex and complicated. He was both familiar and unknown to them, friendly and hostile, astonishing but also exotic and mysterious. Thus, in the representations of Asia, fear and curiosity that spring from the Christian mythological representations are displayed on the medieval monastery maps at the same time. The European perception of 
the Holy Land surrounded by a non-Christian, uncivilized and barbaric world was present on the maps until the Great Geographical Discoveries. Among the vast geodiversity of various distant and exotic countries of the Old World, the attitude of Europeans towards the Orient, which was constantly in sight - was especially complex - they turned their gaze to it in prayers and crises, believing that there is a mythical paradise, the center of the world (Jerusalem) and the Holy Land (Palestine) and places related to the mission of Jesus Christ. Crusades and new geographical discoveries in the Middle Ages showed that the Orient was not a distant country, on the contrary, that it was close (Middle East), and moreover, that parts of this territory were once European. There is a legendary mountain (Ararat) at the top of which is a boat with the inscription Arca Noah - Noah's Ark, and to the east is the river Fl. Contolis (Arax). There are the historical Troy (Troy), Capadocia (Cappadocia), Caladoni (Chalcedonia), Antochia (Antioch), and above all the Holy Land in which Jerusalem is the spiritual and geographical center of the world. Around it are the biblical places of Belehem (Bethlehem), Jericho (Jericho), Cesarea Palestine (Caesarea Palestine), Mare mortuum (Dead Sea), rivers fl. Jor and Dan (forming the Jordan River), Thorens Cedron (Kidron Valley), Stannum Geneser (Sea of Galilee, with fish), M. Syon (Mount Zion), M. Liban(n)s (Lebanese mount.), Bethsaida (Betsaida), Thiberiadis (Tiberias), Niniue (Nineveh), Lachis (Lochis), Acaron, Puteus Josep ("Joseph's pit" in Galilee, where according to biblical legend the brothers sold the prophet Joseph into slavery). Thus, the usual dichotomy of Christians against unbelievers, the righteous against sinners, could only be partially applied in Asia.

The East is at the top of the map and there is also a mythical paradise. According to the book of Genesis: "And the Lord God planted a garden in Eden to the east; and there set up the man whom he had created" (Genesis 2: 8). Between them is the tree of life in the midst of the garden, and the tree of the knowledge of good and evil" (Genesis 2: 9), with the cunning serpent (Genesis 3: 1). Five holy rivers of paradise spring from the fountain of paradise. These are: Tigris - Tigris, Euphrates - Euphrates, Geon - Nile, Phison (Pishon) - maybe Indus and Ganges - Gang. Only four rivers of paradise are mentioned in the Bible: Pishon, Gihon, Hiddekel (Tigris) and Evfrat (Euphrates) (Genesis: 2: 10-14). Paradise as the source of heavenly rivers symbolically represents the source of good (Delumeau, 2000).

The theological question of where world evil comes from is geographically localized on the map in Northeast Asia (top left). It shows an area surrounded by two mountain walls, between which is the Caspian iron gate of Derbent, built by Alexander the Great. This area signifies the 
biblical land of Gog and Magog, which the prophet Ezekiel cursed as the personification of evil (Ezekiel, 39). This myth of the "empire of evil" was identified as Scythia, later as the Mongol Empire, and can be recognized in some recent global geopolitical models, for example in Mackinder's theory of world "Heartland" as the "pivot of history" (Mackinder, 1904), and in phrases about the "axis of evil" (Muir, 2011).

\section{Toponyms in Asia}

[Paradisus] - Paradise (drawing of a fenced paradise garden, figures of Adam and Eve separated by a tree).

Arbor Solis - Tree of the Sun. According to the novel "Alexandrida", two sacred trees of the Sun and the Moon in the east, have prophesied to Alexander the Great that he would conquer the world but not return home, he will die of poisoning in Babylon.

Arbor Lun[e] - Tree of the Moon (Moon Tree).

C[iuitac] Iazaro[n] - On the Psalter List - Thazaron. The name originating from the toponym Lazorum gens, which appears on the Ebstorf map (Miller, 1896), or from "gens optimam Chathmorum" ("the people living in India"), mentioned by Hugh of Saint-Victor in his work "Descriptio mappe mundi" (Gautier Dalche, 1988). Thazaron may refer to the Khazars or Khaaria (Gazar), (Chekin, 2006), or Ariana (persian Aryanem - "the land of the Aryans", sanskrit Āryāvarta - "abode of the Aryas").

C[iuitas] Nisapi - The city of Nisibi in the East is mentioned by Hugo of St. Victor in the $12^{\text {th }}$ century and Aethicus Ister in the $16^{\text {th }}$ century.

Are liberi [et] colu[m]ne erculis - Arcades of Freedom and Pillars of Hercules.

C[iuitas] Pabibotra - City of Polybot (mythical giant).

Phison - Pishon, one of the five rivers of paradise.

Geon - Gihon, one of the rivers of paradise.

Tigris - Tigris, one of the rivers of paradise.

Eufrates - The Euphrates, one of the rivers of paradise, flows from the East to the Armenian Mountains and from there again it springs and flows under the name Euph[er]ates towards the Persian Gulf.

Ganges fl[uuius] - Ganges, one of the rivers of paradise. 
Mare Rubrum et Sinus Persicus (no inscription) - Red Sea and Persian Gulf.

[Transitus Hebreorum] (drawing without inscription) - The Passage of the Jews (Moses' Passage in Red sea, through which the Jews left Egypt).

Regio Coro - Karakorum area, the historical area around the Aral Sea. The city of Karakorum was the seat of Genghis Khan.

Satima - a place mentioned in the Fourth Book of Moses: "And Israel at that time abode in Settim" (4 M, 25:1), and "Ablesatim in the plains of Moab" (4 M, 33: 49)

Turr[is] - from tauris - a tower, perhaps the tower of Babel in Babylon.

P[er]sida - Persia.

Niniue - Nineveh, the ancient city and capital of Assyria, on the East bank of the Tigris River. It is mentioned in several places in the Bible, as an enemy city of the Jews and Israel (Genesis; The Gospel of Matthew, the Gospel of Luke).

C[iuitas] Theodosopolis - Theodosiopolis, a city in eastern Anatolia, today's Erzerum. It was the seat of the episcopate in the late Roman province of Armenia Tertia.

C[iuitas] Elam - Elam, one of the oldest civilizations, the historical core of Iran (provinces Ilam and Khuzistan). The capital of Elam was Suza (founded around $4000 \mathrm{BC}$ ).

C[iuitas] Peliopolis - Heliopolis ("city of the sun"), the former capital of ancient Egypt state, near present-day Cairo. According to Egyptian mythology, this is the birthplace of the god Amon-Ra. In Christian mythology, it is known for the tree of the Virgin Mary, the resting place of the Blessed Virgin Mary, on the way from Israel to Egypt.

C[iuitas] Pesiopolis - Persepolis, located northeast of the present-day city of Shiraz in Iran. It was the capital of the Achaemenid Empire.

Asya Minor - Asia Minor.

M[ons] Orcatoten - Solinus mentions Mount Catoten near Scythia (Collectanea Rerum Memorabilium, 37.1), probably the Armenian Mountains. Atropatene is the old name of Azerbaijan.

Fl[uuius] Ci[n]til[is] - The Contolis River, probably present-day Araks. Herodotus, Virgil (Vergilius) and Strabo mention this river. According to 
some, it is the biblical river Gihon (1 Book of Kings, 1: 33, 38). Pliny (6.10) mentions Cyrus river, in the Caucasus. It springs near Erzerum in Turkey and flows into the Kura River in Azerbaijan. Further east stretches Upper Albania.

M[ons] Libani - The mountains of Lebanon, like the cedar of Lebanon, are mentioned in many places in the Bible.

Troia - Troy, the legendary city and scene of the Troyan War described in Homer's epic Iliad in the $9^{\text {th }}$ or $8^{\text {th }}$ century BC.

Jerusalem - Jerusalem, as the geographical and spiritual center of the world. In the biblical book of the prophets Ezekiel writes, "Thus says the Lord God: This is Jerusalem. I have set her in the center of the nations, with countries all around her" (Ezek. 5: 5). According to the New Testament, Jerusalem and the Holy Land are the spiritual center of Christianity. This idea came to the fore especially during the Crusades in the $13^{\text {th }}-14^{\text {th }}$ century (Woodward, 1985, 1987).

Belehem - Bethlehem, about $10 \mathrm{~km}$ south of Jerusalem, the center of pilgrimage as the birthplace of Jesus Christ (according to the New Testament).

Torrens Cedron-Qidron Stream. According to the New Testament, Jesus Christ crossed this valley many times on his way to the Garden of Gethsemane.

M[ons] Syon - Mount Zion, the hill on which, according to the New Testament, Jesus Christ held a secret supper with the apostles. There is the Church of the Assumption of the Blessed Virgin Mary and the tomb of David.

Stannun Genesar - Lake of Gennesaret (also called Galilee, Lake Tiberias, Kinneret Lake or sea). The drawing of the two fish is reminiscent of the Gospel legend of fishing with the help of Jesus (Luke 5: 1-11; John 21: 1-14).

Thiberiadis - The city of Tiberias, on the shores of the Galilee lake, the center of the region of Galilee. Herod, king of Judea, founded it in the year $20 \mathrm{AD}$ and named it Tiberias, in honour of Roman Emperor Tiberius.

Mare Mortuum - Dead Sea, actually a salt lake into which the Jordan River flows. It is related to the biblical legend of Sodom (Gen. 13:13, 18:16, Ezek. 16:49; Luke 17:29) and Gomorrah (Gen. 14: 9; 2 Mk. 16:23; 4 M. 11:32, etc.).

Ierico - Jericho. Archaeological remains of the city, about 9000 years old, are located on the west coast of the Jordan River, $15 \mathrm{~km}$ upstream from the 
confluence with the Dead Sea. It is mentioned in the Bible as "a city of palms" which the Jews conquered from Canaan. The Romans demolished it in $68 \mathrm{AD}$. It is mentioned in several places in the Old Testament (4. Moses 22: 1 ; 26: 3; 31:12; 33:50; 34:15; 35:1, etc.) and in the New Testament (Hebrews, 11:30; Luke 10:30; 18:35; 19:1).

M[ons] excelsus ubi deabolus statuit d[omi]n[u]m - High mountain where the devil tempted the Lord (according to the Gospel of Matthew, 4:8-10, without the drawing of the mountain).

Betheida - Bethsaida. The New Testament mentions two cities under that name - Bethsaida Julia, where Jesus fed 5000 people with five loaves of bread and two fish (Matt. 14: 19-21;15:34-38) and Bethsaida of Galilee, the birthplace of the apostles Andrew, Peter and Philip.

Corozaim - biblical Chorazin, today Korazim, north of the Galilee lake (Matthew, 11:21).

Azot [us] - Ashdod (a city in Israel).

Cesarea Palestine - Caesarea Palestine, a city between Tel Aviv and Haifa. It was built by Herod the Great and dedicated to Octavian Augustus Caesar, hence his name. It was the administrative center of the Roman province of Judea, the early Christian center and the capital of the Byzantine province of Palestine Prima.

Acaron - The city of Ako or Accra in Israel, located on the shores of the Mediterranean Sea. After the crusade conquest of Jerusalem in 1187, Accra became the capital of the Crusader kingdom of Jerusalem, which existed until 1291. The Order of the Teutonic Knights was founded in Accra.

Ior - Jor, the Jordan River, in which John the Baptist baptized Jesus (Matthew $3: 13)$.

Dan - the Dan River, in Arabic Leddan, a left tributary of the Jordan River in Israel. It springs from Tel Dan (Tell al-Qādīi), near the biblical city of Dan, formerly called Laish (Judges, 18:29), in the far north of Israel (Judges, 20:1).

C[iuitas] Lachis - Lachish (Tel-Lachish), a city in the kingdom of Judah. The siege of the Assyrians and the fall of Lachish is mentioned in the Bible (Jeremiah, 34:7; Isaiah, 36:2; 37:8; Nehemiah, 11:30; diary, 32:9).

Arca Noe - Noah's Ark (with a drawing of an ark on top of Ararat).

Armenia - Armenia. 
Calcidonia - Chalcedon, today part of Istanbul, called Kadıköy. In the temple The Fourth Ecumenical Council was held in Chalcedon by the Great Martyr Jefimija in 451.

Albania Superior - Upper Albania

Albania Inferior - Lower Albania (in Azerbaijan)

C[iuitas] Spartan - The city of Pertan or Parthan, in ancient Caucasian Albania. On some others medieval mappaemundi, Parthan is situated in the province of Armenia or Parthia. Parthan in Albania can only be seen on the Psalter Map, which is the result of the wrong localization of the city of Parthan in Armenia.

C[iuitas] Parthia - Parthia (area in northeastern Iran).

Amazones hic manent - "Amazon women live here". In Greek mythology, the Amazon women are women warriors. According to Herodotus, their existence can be compared to that of the Scythians and Sarmatians.

Are Alexandri - Alexander's sacrifice (Altar). Altars as sacrifices can serve as markers for the four sides of the inhabited world (oecumene): Pillars of Bakh (Bakhus) in the East, Hercules' Pillars in the West, the Altars of the Philaeni (Arae Philaeno'rum) in the South, near the bottom of the Great Syrtis, and Alexander's Altars in the North (Джаксон, Коновалова, Подостинов, Фролов, 2017). Alexander the Great erected sacrifices as altars in several places. For example, when he decided to stop the campaign in India, he built 12 altars to the gods on the banks of the river Hyphasis and a pillar with the inscription: "Alexander the Great stopped here".

Fl[uuius] H[er]mes - The river of Hermus, flowed from central Phrygia through Lydia into the Aegean Sea. In Greek mythology, Hermus is the god of river from Lydia in Anatolia.

C[ivitas] Antiochia - Antioch, today's city of Antakya in Turkey, near the border with Syria. It is mentioned in the New Testament (Acts, 6). The Church of Antioch is one of the oldest, founded in 37. The famous Council of Antioch was held there in 341. The Crusaders conquered Antioch in 1098, which they held until 1268.

C[iuitas] Capadocia - City of Cappadocia.

Arumphei - Arumphei (island in the north).

Abatiam - Albatia island north of Scythia, mentioned by Solinus (19: 6). 
Murus Alexandri - Alexander's wall with a gate is considered to represent the Great Gorgan Wall (Gorgan is the ancient Greek name for Hyrcania). It's a brick wall in between the Caspian Sea and Mount Elbrus, $195 \mathrm{~km}$ long and 6-10 $\mathrm{m}$ wide. Archaeological research has established that the wall was erected before Alexander, during the Sassanid dynasty, as a defense against nomadic tribes from Central Asia. The wall is an association with the biblical legend of Gog and Magog (Genesis, 10: 2; Ezekiel, 38 and 39; Apocalypse, 20:7-9). It is also mentioned in the Qur' an (18, 93 and 21, 96), on the Hereford and Ebstorf maps. According to the legend of Alexander, the purpose of the wall was to keep the evil Gog, whose hordes from the kingdom of Magog were to flood the world on Judgment Day. Some authors mistakenly identify it as the Great Wall of China (Anderson, 1932; Woodward, 1987), and some as the Caspian Iron Gate of Derbent (in the Republic of Dagestan), built by Alexander the Great.

Pr[ouincia] Hircania - Province of Hyrcania. Hyrcania was an area in Persia along southeastern rim of the Caspian Sea.

C[iuitas] Licia - City of Lycia.

Octogora - with a pyramidal sign as a city. The city is marked on the Hereford map as Octoricirus, and on the Ebstorf map of as Ottorogorra. According to Orosius, this is the name of the river (1.2.13).

C[iuitas] Saphiri - Safris city (Nukusafris). Nukus in Uzbekistan on the Amu Darya River.

C[iuitas] Carnis - Orosius mentions two cities of similar name: Carras (Orosius, 1.2.41) and Carris (1.2.42).

C[iuitas] Ciropolis - Kiropolis, founded by Cyrus the Great 544 BC on the North of the Achaemenid Empire.

\section{Geographical contents in Europe}

It could be expected that the geographical area of Europe is presented with the least errors. But it is not so. The aim of the author was primarily to show the places of worship and centers important for Western Christianity. Psalm 38 mentions Jerusalem, Rome, Santiago de Campostela as pilgrimage destinations. The Psalter World Map shows several pilgrimage centers established in the $12^{\text {th }}$ and $13^{\text {th }}$ centuries and several cities selected as landmarks for pilgrims: Constantinople, Cluni in the region of Burgundy, Paris, Aquitania, Lyon, Rome and Canterbury, Colonia (Cologne), Barcelona, London. 


\section{Toponyms in Europe}

Sclaueni Occidentalis - Western Slavs.

Ruscita - Ruthenia or Little Russia? K. Miller read it as Irii Scite. That's why it is not clear whether the cartographer had in mind the Russians or the Scythians (Chekin, 2006). Ruscita is further West than western Sclavinia, and may mean Ruthenia or Galicia-Volyn Russia (the term Little Russia here means the medieval state of Ukraine).

Olcus - Olta, a left tributary of the Danube in Romania. Miller thinks it's the Volga or Volkhov, but they are not tributaries of the Danube.

Danubius - the river Danube.

Sarmatica - Sarmatia. The Sarmatians are a people whose tribes inhabited in ancient times areas East and West of the River Don (Tanais).

Citia - Scythia. Scythian tribes inhabited southern Russia and central Asia. On this map Citia is positioned west of Sarmatia.

Citha - Little Scythia, an ancient region south of the lower Danube, in presentday Dobrogea (Miller, 1896). The letter $r$ is similar to $t$, and the letter $h$ is like b, so this name could mean Cirba (Serbia). That would be the first cartographic appearance of the name Serbia. On Pietro Vesconte's map from 1320, Se[r]uia or Se[r]via is marked. On the map of A. Dalorto from 1325 we find the name Seruia. On the map of Angelino Dulcert from 1339, Seruia and the city of Scopi (Skopje) are marked with the flag of a red double-headed eagle on a golden yellow background, which is the first artistic representation of the Serbian state flag (Соловјев, 1936). In 1448, Andreas Walsperger wrote the name Serfia on her map of the planisphere, similar to the Arabic Sirfia. On Fra Mauro's map from 1459, Servia is marked.

Hu[n]garia - Hungaria, Hungary. The name Hūgaria (Hungary) may be interprets as $\mathrm{Bu}[\mathrm{r}]$ garia (Bulgaria) (Орачев, 2005). By analogy, the neighboring name Citha would mean Cirba (Serbia).

Dalmatia - a Roman province along the eastern coast of the Adriatic Sea, separated from Liburnia by the river Titius (Krka river) and from the Greek Illyria in the south by the River Drilo (Drin). It was the homeland of St. Jerome.

Co[n]stantinopolis - Constantinople, today Istanbul. 
Grecia - Greece, the cradle of ancient Greek civilization.

Larissa - Larissa, a city in Thessaly.

Archaia - Arcadia (or Achaia?).

Macedonia - Macedonia, a country in the north of ancient Greece. It was originally called Emathia, and was significantly expanded by the conquests of Philip, the father of Alexander the Great. He annexed to his kingdom: Paeonia in the north; part of Thrace in the east to the River Nestos, as a district which the Thracians commonly called Macedonia Adiecta; the Halkidiki peninsula in the south; and in the west part of Illyria to Lake Lychnitis (Thurston, 1898).

Roma - Rome, the capital of the Roman Empire and the seat of the Roman Catholic Pope.

Cisilia - Sicily, an island.

Creta - Crete, an island.

Calipso - Calypso. Mythical island according to Homer's Odyssey.

Mare - Sea (unknown).

Saxonia - Saxony, part of Germany.

Ala - Halle, Saale in Germany.

Coloni[a] - Cologne, an ancient Roman city on the Rhine. The relics of the Holy Three Wise Men are kept in the famous Cologne Cathedral, which were brought to Cologne in 1164 as great shrines. According to the New Testament, sages from the East first came to worship the newborn Jesus and to present him as a king with gold, as a god with incense, and as a man with a noble myrrh (Matthew 2: 1-2, 11).

Bri[tannia] - Britain.

Walni - Wales.

Scocia - Scotland.

Ibernia - Hibernia, Ireland.

Cornu[bia] - Cornwall.

Bolonia - Boulogne-sur-Mer.

Burgu[n]dia - Former Duchy of Burgundy, today mainly the region of Burgundy. 
Parisius - Paris (the icon is shown on the island of Île de la Citè).

Bel[gis] - City of Belgis (?). According to Isidore (14.4.26): Belgis autem civitas est Galliae, a quo Belgica provincia dicta est. [The city of Belgis is Gaelic, after which the province of Belgica is named].

Normannia - Normandy.

Equitania - Aquitaine. Normandy and Aquitaine were part of the Angevin Empire (Fr. - L'Empire Plantagenêt), which existed between 1154 and 1242. King Henry III of England considered them his hereditary lands. Because of that, they were probably marked on the map, while the other provinces of France were left out.

Lugdune[n]sis - Roman Province Gallia Lugdunensis. Its capital was Lugdunum (the current site of Lyon).

Barcinona - Barcelona.

Hispania - Spain.

Galicia - Galicia. Area in the northwest of the Iberian Peninsula. The capital city Santiago de Compostela has been one of the most important places of pilgrimage in Catholicism since the Middle Ages (the Camino de Santiago route), because relics of St. James the Great lay there (hence the name of the city of Santiago).

[Colum[p]ne Herculis] - Pillars of Hercules (drawing next to Gibraltar).

[Mons Pireneus] - Pyrenees mountains (drawing without inscription).

[Alpes] - Alpine mountains (drawing without inscription).

M[ons] Riphei - Riphean mountains, north of the Pontus, probably the Urals. A nameless river springs there, probably Tanais (Don), or perhaps Borysthenes (Dnieper), although none of them in reality spring from high mountains.

Ip[er]bor[e]a - Hyperborea. Hyperboreans are the mythical northernmost people. Solinus (16.1) mentions the Hyperboreans as blessed people. Maybe Lapps?

Mons Sueuus - Swabian mountains from the term Svevi - Schwabe. That term may also mean the Swedish mountains (Chekin, 2006). Further west is Saxony, which stretches, according to maps, on the shores of the North Ocean.

Norwegi[a] - Norway (shown as an island). 
Rivers without names are: Rhône and Saône, Rhine with two tributaries, Tiber and Arno.

\section{Geographical contents in Africa}

The name Africa is not written on this map. The ancient Greeks called the African continent Libya. The Romans meant only the northern, Mediterranean part of the continent, which they divided into provinces. The border between Asia and Africa was not clearly defined. According to Orosius (1.2.8), Africa begins in Alexandria. On the Psalter World Map, Egyptus (Egypt) and Athiopia (Ethiopia) are marked, which were considered part of Asia, and to the west, the Nile Delta, North Africa and the Atlas Mountains area are exaggerated.

Sub-Saharan Africa is shown only as a zone with fourteen mythical monstrous half-human races. Pliny the Elder in his work "Naturalis historia" (The Natural History), around $77 \mathrm{AD}$, described a series of monstrous races in "India" (which was the collective name for the entire Far East) and in "Ethiopia" (or Africa), and they were adapted by Julius Solinus in the $3^{\text {rd }}$ century. For example, on the southern margin of the Psalter Map we find drawings of the following fourteen monstrous races, which were identified by Conrad Miller (Miller, 1895), based on the description of Pliny and Solinus:

1. [Phanesii] - Panotti, a people with huge ears with which they can cover themselves;

2. [Sine naribus] - People without noses, whose faces are weakly expressed;

3. [Gens ora concreta] - People with other mouths, who feed themselves by drinking through a reed tube;

4. [Gentes carent lingua] - People without tongues, use nodding and gestures to talk;

5. [Psambari] - People without ears;

6. [Marmini Ethiopes] - Mauritanians or maritime Ethiopians - people with four eyes, and therefore very accurate in archery;

7. [Sciapod / Monoculi] - People with one very large foot and one eye, lying on their back and use their foot as an umbrella;

8. [Amyctreae] (Gens labro prominente) - People with oversized lower lips used for face protection from solar heat; 
9. [Blemmye] - People who have eyes and mouths on their chests;

10. [Oculis in humeris] - Epiphagi, people without a head with eyes on their shoulders;

11. [Trocodites] - Troglodytes, inhabitants of caves who eat wild animals and snakes;

12. [Artobatitis] - People who walks on all four legs;

13. [Anthropophagi] - Cannibals;

14. [Antropophagic Cynocephales] - Cannibals with dog heads.

\section{Toponyms in Africa}

Ethiopia - Ethiopia, a country south of Egypt, which embraced Christianity very early.

Nilus fl[uuius] - The River Nile, with seven tributaries in the Delta.

Stannum - Mountain lake, source of the River Nile.

Montes Nubie - Nubian Mountains.

Egyptus - Egypt (biblical Mișr).

Memphis - Memphis, the first imperial city in history. Founded around 3500 $\mathrm{BC}$ as an administrative the center of Upper and Lower Egypt, $25 \mathrm{~km}$ south of present-day Cairo.

Alexandria - Alexandria.

Babilonia - the city of Cairo in Egypt. It should not be confused with Babilonia Magna in Mesopotamia (Савић, 2015).

C[iuitas] Saltabri - City of Saltabri (unidentified).

Damiete - Damietta, Tamiatis, a city in the Nile Delta. In the $12^{\text {th }}$ and $13^{\text {th }}$ centuries, it was targeted on several occasions by crusaders as a strategically important point for the conquest of Egypt and Palestine.

Tapnis - Daphnae, today's al-Dafna, an ancient city in Egypt, on the road from Pelusium to Memphis. Many Jews settled here after the destruction of Jerusalem. It is mentioned in the Bible as Tahpanhes (Jeremiah, 43: 7,8; 44: $1 ; 46: 14$ ) or Tehaphnehes (Ezekiel, 30:18). 
Pelusium - Pelusium, Pelusion, a city in Sinai, today's Tell el-Farama. It is mentioned in the book the prophet Ezekiel (30:15).

Beronice - Berenice, today's city of Benghazi in Libya. Ancient Greek colony Hesperides (Eusperides), later renamed Berenice (probably after Berenice, an Egyptian princess, daughter of King Ptolemy II and the Seleucid queen). The city was one of the five cities of Pentapolis, Cyrenaica, an ancient Christian episcopate.

P[rouincia] Lexa[n]dria - Province of Alexandria. Instead of the initial letter A is a hyphen.

Terra arenos et sterilis - Sandy and barren land (Sahara desert).

Are Philenor[um] - The Altars of the Philaeni, on the border between Carthage and Cyrene. Two landmarks on the place where the two Philaeni brothers from Carthage agreed to be buried alive in order to mark the border and establish peace. They are mentioned by Strabo (III, 171; XVII, 836), Polybius (II. Cc .; III. 39); Salust South. (19, 79); Pliny (V. 4); Mela (I. 7: 6); Skilax (p. 47).

Cartago - Carthage, a city and state in today's Tunisia.

Zeugis r [egio] - Zeugitāna Regio, northern part of Tunisia, former northern region of Africa Propria in Carthage Empire, which surrounded Carthage. The area of Byzacium or Byzacena stretched to the south.

Mauritania - Roman Mauretania stretched between the Atlantic in the West, the Mediterranean in the North, Numidia to the East, and Getulia to the South. The Romans came to this land during the war against Jugurtha 106 BC. In the time of Caligula in $40 \mathrm{AD}$, it became a de facto Roman province, and was formally constituted as such by Claudius, a large part of Numidia was added to it and divided along the river Malva into a western part, called Tingitana after the capital Tingis (Tangier), and an eastern part called Caesarea, after the capital of Julius Caesar (Zershell). In the later division of the empire under Diocletian and Constantine, the eastern part of Mauritania Cesariensis, from Saldae to Ampsaga, was proclaimed a new province and named Mauritania Sitifensis after the city of Setifs. Under the later Roman emperors, Mauritania had a large number of episcopal chairs (Thurston, 1898).

M[ons] Atlans - Atlas Mountains.

C[iuitas] Oliopolim - Heliopolis. 
Monasterium S[ancti] Pet[ri] - Monastery of St. Peter (marked with a triangle with a cross on top). It is about the Orthodox Coptic monastery of St. Anthony in the oasis of the Eastern desert in Egypt, which has an ancient church dedicated to St. Peter and Paul.

Orrea Iosep - Joseph's barn. They are mentioned in the Old Testament (Genesis: 40). They were marked with three pyramidal signs, because the pyramids were considered to be barns.

Presuli duo manent - Two bishops stayed here. Regarding Orrea Joseph, this suggests that two bishops always resided at the pyramids.

C[iuitas] Garema - Germa in Libya. The ancient name of Garama. It was the capital of Garamantide - the land of the Garamantes, from the $11^{\text {th }}$ century BC to 669 AD.

Getulia - Gaetulia (Orosius, 1.2.90) and Gaetulos (Isidore, 14.5.6), an area in north-west

Africa inhabited by Gaetuli (Romanized name for Berbers).

P[rouincia] Mathabres - Province of Natabres. It is also mentioned on the Hereford map.

Gorgade[s] - Cape Verde (?)

Tacona - Tarragona (?), as an island. Orosius (1.2.104) mentions the city of Tarragona on the island of Mallorca. 


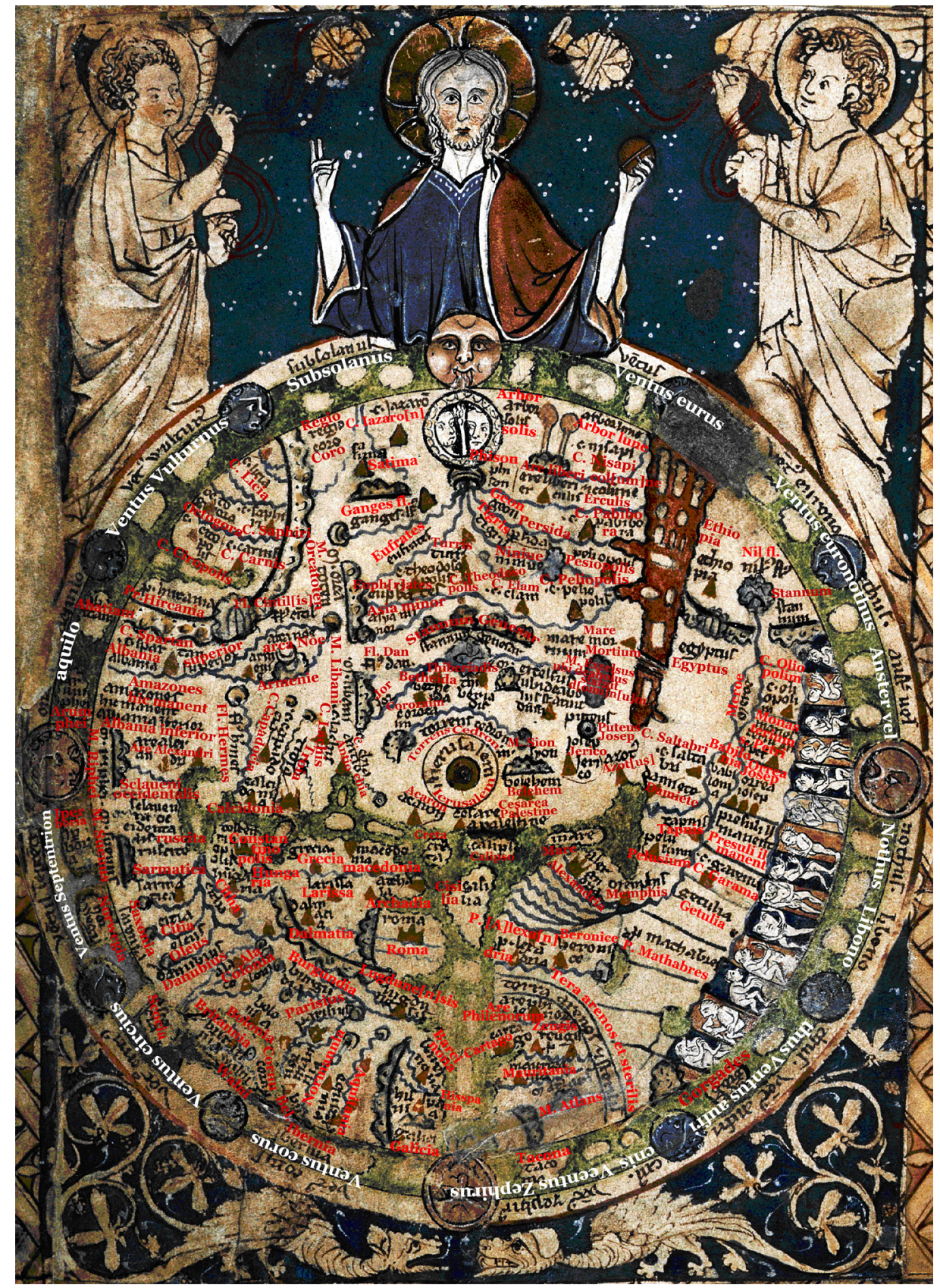

Figure 1. The London Psalter Map, BL Add. MS 28681, f.9r (red letter inscription by M. Grčić) 


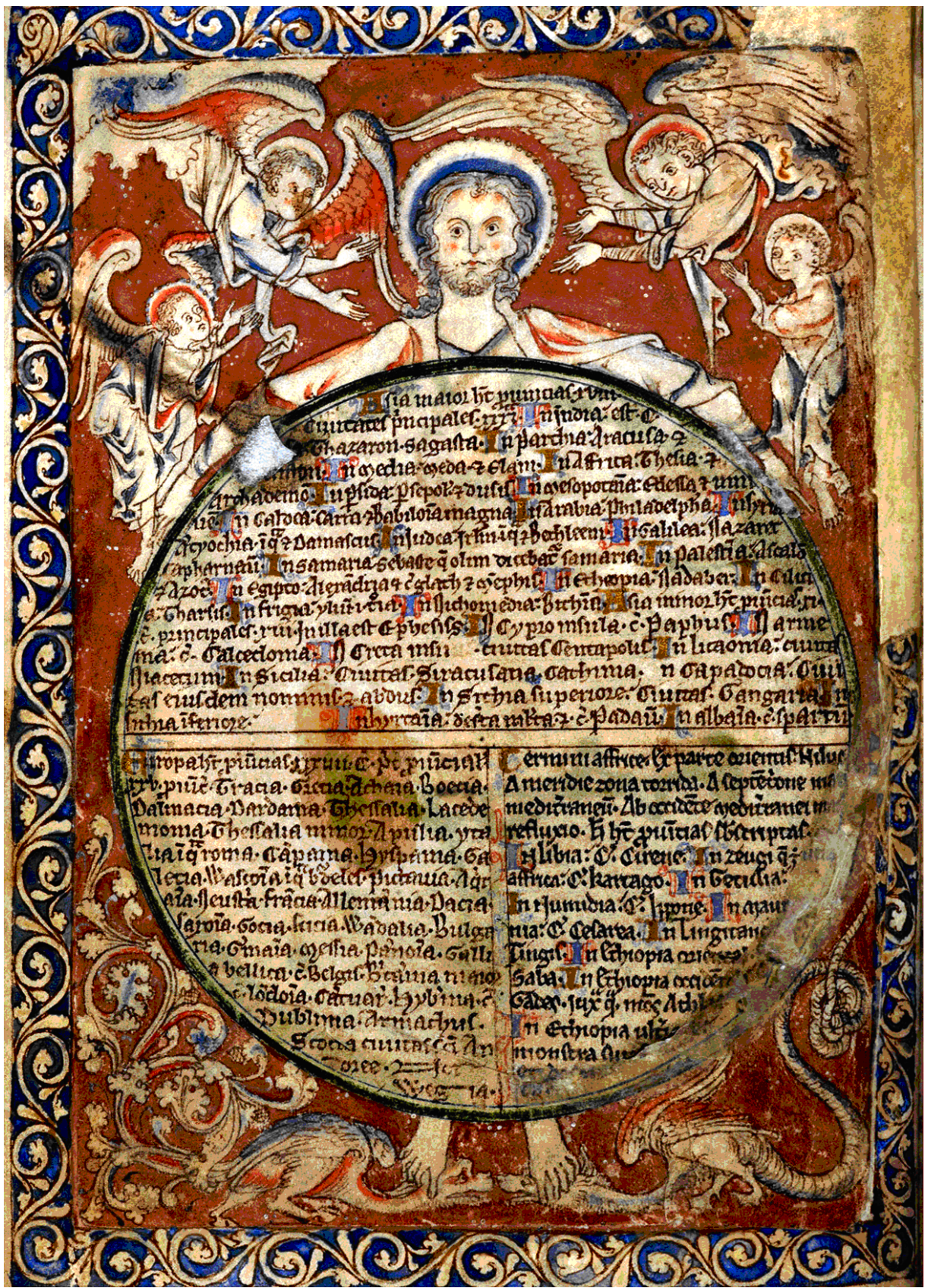

Figure 2. Psalter List Map, $13^{\text {th }}$ century, British Library Additional MS 28681, f. 9 v 


\section{Iconography and symbolism of the map of the Psalter List}

The Psalter List Map is a schematic T-O type world map that contains a list of areas and cities classified by continents of the Old World. This map is significantly different from the previous map on the obverse. The textual content in a circle with a diameter of $17 \mathrm{~cm}$, "provides the observer with the opportunity to participate in a dynamic devotional form that has its roots in the geography of humanity and the earthly kingdom." Christ as the creator presides over the macrocosm in the act of creation" (Brott, 2018).

The Psalter List Map shows the figure of Jesus Christ standing and hugging the Earth's disk divided into three parts, which represent the continents of Asia, Europe and Africa. In that illustration, the Earth's circle covers almost the entire body of Jesus. His head is above the world, which he hugs with open arms, while standing barefoot on the heads of two feathered dragons, under the Earth's disk. The fact that the head of Jesus is above the world, the Earth's disk on the body of Jesus and the dragons under the feet, symbolizes that God controls the heavenly, earthly and underground world. Two-legged dragons with a snake-like tail are depicted as trickery and evil. The serpent is the only living thing that God has cursed (Genesis 3:15) and punished as the embodiment of evil (Romans 16:20; Hebrews 2:14; 1 John 3: 8; Revelation, 12: 7,17). In the upper left and right corners of the heavenly vault are four winged angels who gesture with their hands towards the central figure, as if presenting Christ the Savior to the world. Alternatively, they may be helping Christ in the Last Judgment. The circular disk, which represents the world, covers the whole body of Christ, so that only his head, hands embracing the world and feet can be seen. There are opinions that this figure represents Adam, who shows the four corners of the world with his body, but the presence of four angels indicates that it is still Jesus Christ, who is here in the role of another Adam.

\section{Analysis of geographical contents of the Psalter List Maps}

The Psalter List Map contains the names of 75 areas and 77 cities in Asia, Africa, and Europe (Brott, 2018). In addition, 39 initials identify areas (provinces). The map shows twelve places from the text of the Psalter: Egypt, Tarshish, Arabia, Saba, Judea, Jerusalem, Babylon, the Jordan River, Mesopotamia, Syria, Ethiopia and Assyria. Egypt is listed in the Asia area, while Saba is listed in the Africa area, in the province of Ethiopia. Some of the geographical names on the Psalter List Map are not marked on the 
previous Psalter World Map, for example: Wasconia (Gascony), Pictavia, Neustria, France, Alemannia, Saxonia, Gothia, Wadelia, Bulgaria. Some names exist on both maps, but with different spellings, for example Jazar appears on the map and Tazar appears on the Psalter List. The order of the names of places may correspond to their place on the map, but they could also be arranged according to the route of travel starting from the southeast to the northwest. Their appearance is organized by landmarks more than by longitude and latitude, with the indication of places, in order for travelers to prepare for the cities they will meet in each region while traveling a certain route. The European area on the Psalter List Map may have been influenced by pilgrimage routes and itineraries but the cities listed do not form a clear travel route nor do they appear to coincide with any known pilgrimage route. Perhaps this Psalter List highlights some of the historically and religiously significant cities on the continent. Each city could serve to remind the observer to recall some information related to that location. The following is a list of toponyms by continent, in the order shown on the original.

\section{Geographical list of areas and cities in Asia}

- Afia maior h[abe]t pr[o]uinciaf. xviii.ciuitates p[ri]ncipales. xxxi[a]. - Greater Asia has 18 provinces [i] 31 capitals.

- In India: eft.c(iuitates).[illegible] Thazaron.Sagafta . - In India, the cities of Thazaron [and] Sagasta. Thazaron (Jazaron on the Psalter World Map). Related to the name Lazorum gens, which appears on the Ebstorf map (Miller, 1896), or "gens optimam Cathmorum" (people who reside in India) which appears in the work of Hugh of St. Victor under the title "Descriptio mappae mundi". Sagasta has not been identified, perhaps Sagadan mentioned by Hugh of St. Victor (Gautier Dalché, 1988).

- In Parthia: Aracufa.(et) [*2tisfon] - - In Parthia: Cities Arachosia and Ktesiphon. Parthia is a historical area in northeastern Iran, which encompassed the western half of Greater Khorasan and was the political and cultural core of the Parthian Empire. Arachosia is an ancient territory in Afghanistan and Pakistan, with the capital Alexandria (today's Kandahar). Ktesiphon was the capital of the Parthian and Sasanian empires in Mesopotamia.

- In Media: Meda (et) Elam - - In Media: Meda and Elam. Media was the first Iranian empire, from the end of the $8^{\text {th }}$ to the middle of the $6^{\text {th }}$ centry BC. 
Elam is an ancient civilization (2700 - $539 \mathrm{BC})$ in the west and southwest of present-day Iran (Ilam province, lowland Khuzestan) and parts of Iraq.

- In Affrica: Thefia.(et) archademo(n) - Thesia (?) - In Africa (Africa is incorrect name for Assyria): Thesia (perhaps Theodosiopolis, Erzurum) and Archademon (perhaps Archimedon, mentioned by Hugh of St. Victor in connection with Assyria) (Wacha and Lewrnier, 2019).

- In P(er)fida: P(er)fepol(is) (et)dufif - In Persia: Persepolis and Dusis. Persia is today's Iran. Persepolis, the ancient Persian name of Parsa, was the capital of the Achaemenid Empire (550 - 330 BC). It was built by Darius I, about $70 \mathrm{~km}$ northeast of the present-day city of Shiraz in the Iranian province of Fars. Dusis, more precisely Susis is Susa, one of the residences of Darius I.

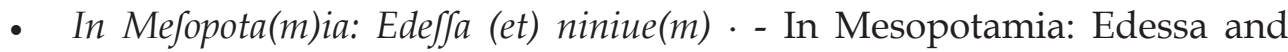
Nineveh. Edesa is the predecessor of today's city of Urfa, in the province of Shanliurfa in upper Mesopotamia. It is important in Christianity as the birthplace of the apostle Thaddeus and the place where the Holy Mandylion was located (the miraculous icon of Jesus Christ on canvas). During the First Crusade, the Crusaders founded the county of Edessa in 1099. Niniva - the biblical "great city" (Jonah 3:2, 4:1), on the east bank of the Tigris, in present-day Mosul in northern Iraq.

- In Caldea: Carra (et) Babilo(n)ia magna - In Chaldea: Carra and Babylon (Babilonia Magna). Chaldea is the ancient name for Mesopotamia. It is known that the biblical Babylon was in Chaldea. According to Strabo, "New Babylon is a fortress, built by Babylonian exiles near Memphis in the time of the Persian kings ... From there you can clearly see the pyramids on the opposite bank of the river near Memphis, which is nearby" (Strabo, XVII, I, 30). In one document from the first half of the $12^{\text {th }}$ century, it is said that Caesarea Palestine under the Saracens flourished between Babylon and Babylonia, that is, between Baldach (Baghdad) in Persia and Memphis in Egypt" (Савић, 2015). Ludolf von Sucheim says that "New Babylon and Cairo (Carra / Alcayre) are two extremely large cities, not far from each other, located on the Nile, a paradise river." It then goes on to call the city, which was once called Carra (Cairo) now Alcayre. Ludolf goes on to talk about "Old Babylon" which is located northeast, about thirty days away from the Nile Delta (Deycks, ed. 1851; Ludolphus, digital 2013). "Pilgrims and travelers used the name Babylon for both cities - Chaldean and Egyptian" (Laurent, 1873). 
- In Arabia: Philadelphia(i) - In Arabia: Philadelphia. This is Amman, which is referred to in the Bible as "Rabbath Ammon". Egyptian King Ptolemy II Philadelphus ruled the city from 285 to 246 BC and renamed it after his name in Philadelphia (meaning "brotherly love").

- In fyria: A(n)tyochia.i(n) q(ua) (et) Damafcuf - In Syria: where Antioch and Damascus are. Antioch (present-day Antakya in Turkey) is mentioned in the New Testament (Acts 6: 5; 11:21, 27; 13: 1; 15:23, 30). The Church of Antioch is one of the oldest Christian communities, founded in 37. Its first bishop was the Holy Apostle Peter. The Church Council of Antioch was held in 341. Damascus is also mentioned in the New Testament (Acts 9: $2,3,8,10,19,27)$.

- In Iudea: I(e)r(usa)l(e)m i(n) q(ua) (et) Bethleem - In Judea: in which are Jerusalem and Bethlehem. Judea is a geographical area and a former Roman province. According to the New Testament, Jesus Christ was born in Bethlehem, and he was crucified in Jerusalem.

- In Galilea: Nazaret Caphernau(m) - In Galilee, Nazareth and Capernaum. Galilee is a predominantly mountainous region in northern Israel. Nazareth is mentioned in the New Testament as the place where Jesus Christ spent his childhood. In the First Crusade, the Crusaders conquered Galilee and proclaimed Nazareth as its capital (1099). Capernaum - a city in the north of the Sea of Galilee. It is mentioned in the New Testament as a place of preaching Jesus Christ and miraculous healing of people.

- In samaria sebafte q(ue) olim dicebat(ur) Samaria - In Samaria, Sebaste[a] which was once called Samaria. A mountainous area and city (Hebrew - Shomron) in the northwestern part of Eretz Yisrael ("Land of Israel").

- In Palefti(n)a Ascalo(n) (et) Azot(us) - In Palestine, Ashkelon and Azotus. Ashkelon, the birthplace of King Herod. It is mentioned in the Bible (Joshua 13: 3; 1 Samuel 6:17; 2 Samuel 1:20; Judges 1:18; Jeremiah 25:20; 47: $5,7)$. The Crusaders conquered it in 1153. Azotus (Ashdod, now Esdud). It is mentioned in the Bible (Joshua, 1:22; 13: 3; 15:46, 47; 1 Samuel 5: 1,2; 1 Isaiah 20: 1; Jeremiah 25:20; Zechariah 9: 6; 2 Chronicles , 26: 6).

- In egipto: Alexa(n)dria (et) c(iuitates) glath (et) Me(m)phif - - In Egypt: Alexandria and the cities of Glath and Memphis. Glath has not been identified. Memphis - the ancient capital of Egypt, south of modern Cairo.

- In Etheopia: Nadaber - In Ethiopia: Nadabah. 
- In Cilicia-Tharfif - Tarsus city in Cilicia (Cilicia was located on the border of Asia Minor with Syria), which is mentioned in the Bible (Jonah, 1: 3; 4: 2). Today's Tarsus in Turkey.

- In frigia: yliu(m).(et).t(ro)ia. - In Phrygia: Ilium and Troy (mentioned in the Iliad).

- In Nichomedia: Bithi(ni)a. - In Nicomedia: Bithynia. In fact, it's the other way around. Bithynia is a province on the northern coast of Asia Minor. It is mentioned in the New Testament (Acts 16:7; Peter, 1:1). One of its cities was Chalcedon. Nicomedia or Nicomidia is an ancient city on the site of today's Izmit in Bithynia. It was founded and named after the Bithynian king Nicomedes I of Bithynia.

- Afia minor h(abe)t $p(r o) u i(n) c i a(s) \cdot x i \cdot c($ iuitates).principalef.xiii.In illa eft Ephefifs -Asia Minor has eleven provinces, thirteen capitals. In it is Ephesus. Ephesus is one of the two most important ancient cities in Asia Minor (the other is Smyrna). It is mentioned in several places in the Acts of the Apostles and the Epistles of St. Paul in the New Testament.

- In Cypro infula · c(iuitas) - Paphuf. - On the island of Cyprus the city of Paphos (birthplace of Aphrodite. Visited by St. Paul).

- In armenia.c(iuitas).Calcedonia. - In Armenia Halkidon. In the ancient Greek city of Chalcedon, the Fourth Ecumenical Council was held in 451. Today, the city is part of Istanbul called Kadikoy (Turkish: Kadiköy Judge's Village).

- In Creta infu[la].ciuitas Centapolif - On the island of Crete, the city of Centapolis. Maybe Pentapolis. Crete and Cyrenaica formed a Roman province in 27 BC. Cyrenaica was called Pentapolis.

- In licaonia.ciuitaf Niacetum. - In Lycaonia, the city of Nicaea. Lycaonia is an area in the interior of Asia Minor. Nicaea or Iznik is an ancient city in Anatolia. It is known in church history as the venue of the First and Second Ecumenical Councils of Nicaea).

- In Sicilia.Ciuitaf-Siracufana. Cathinia. - In Sicily the city of Syracuse [and] Catania. Syracuse is known as the place where Archimedes lived, and for the Christian catacombs from early Christianity (Acts 28:12). The Kingdom of Sicily was founded by the Normans in 1130. Catania is the second largest city in Sicily, close to Mount Etna.

- II]n Capadocia.Ciuitas eiufdem nominif.(et)(·)abduf - In Cappadocia the city of the same name and Abdus. Cappadocia is a vast province in eastern Asia Minor. It is mentioned in the New Testament (Acts 2: 9; 1 Peter, 1:1). 
- In Sithia fuperiore: Ciuitaf.Gangaria - In Upper Scythia the city of Gangaria (unidentified).

- In fithia $i(n)$ feriore .... - In Lower Scythia ...

- In hyrca(n)ia.def(er)ta m(u)lta (et).c(iuitas).Padau(m). - In Hyrcania many deserts and the city of Padaum. Hyrcania is a historical-geographical region southeast of the Caspian Sea, in today's Iran and Turkmenistan. Padaum has not been identified.

- In alba(n)ia.c(iuitas).jpartu(n) - In Albania, the city of Spartun. It means Caucasian Albania. The city of Spartun or Partan on other medieval mappae mundi is situated within the province of Armenia or Parthia.

\section{Geographical list of areas and cities in Europe}

- Europa h(abe)t p(ro)ui(n)ciaf.xxxiiii.c(iuitates).p(rin)c(ipales) p(ro)ui(n) cial(es).xxv - Europe has 34 provinces, [and] 25 main provincial cities.

- $\quad p(r o) u i(n) c(i e)$ Tracia - province of Thrace. Historical-geographical area in the southeast of the Balkan Peninsula, divided between Bulgaria, Greece and Turkey.

- Grecia.-Greece.

- Achaia. - Achaia.

- Boetia. - Boeotia.

- Dalmatia. - Dalmatia.

- Dardania - - Dardania. A Roman province formed by Emperor Diocletian in 284, in the southern part of Upper Moesia, with the capital Naissus.

- Theffalia - Thessaly.

- Lacedemonia - - Lacedaemon, the ancient name for Sparta.

- Thefsalia minor - Little Thessaly.

- Apulia.-Apulia.

- Ytalia i(n) q(ua)roma - Italy where Rome is.

- $C a(m) p a n i a \cdot-C a m p a n i a$

- Hyjpania.-Spain.

- Galecia - Galicia, an area in the northwest of the Iberian Peninsula, in Spain. 
- Wafco (n)ia i(n) q(ua) b(or)dele - - Gascony, in which Bordeaux is.

- Pictavia - Poitiers, a city in France. In the battle of Poitiers in 732, the French stopped the Moorish invasion of Central Europe.

- Aq(ui)ta(n)ia. - Aquitaine, region of France.

- Neufstria - Neustria means "western kingdom" in the northwest of the Frankish state during the Merovingian dynasty, from the $6^{\text {th }}$ to the $8^{\text {th }}$ century, as opposed to Austrasia or the "eastern kingdom" or Austria.

- $\operatorname{Franc}(n)$ cia - France.

- Allemannia- - Germany.

- Dacia - Dacia (lat. Dacia), a state created by the Dacians in the first century, in much of present-day Romania. On the Ebsdorf map from 1234, it is marked: Dacia regio et Gotia orientalis.

- Jaxonia- -Saxony.

- Gocia - Gothia, a Christian principality on the Crimean peninsula, from the $13^{\text {th }}$ to the $15^{\text {th }}$ century. It was also called the principality of Theodore and was one of the hereditary states of the Byzantine Empire after the crusade in 1204.

- Scicia-Scythia.

- Wa(n)dalia - Vandalia. Many researchers, on the basis of ancient sources, equate the Wends (Slavs) with the Vandals, who were divided into tribes and founded kingdoms throughout the Slavic area. The Germans called the Lusatian Sorbs Wendels (Vandals).

- Bulgaria. - Bulgaria

- G(er)ma(n)ia. - Germania (Roman name for territories inhabited by Germanic tribes).

- Meffia - Moesia, a Roman province in parts of present-day Serbia and Bulgaria. It was divided in the time of Domitian, 85 or 86, into Upper and Lower Moesia.

- $\quad P a(n) n o(n) i a$ - - Pannonia, a Roman province. At the beginning of the $2^{\text {nd }}$ century, it was administratively divided into Upper Pannonia (Pannonia Superior) in the West and Lower Pannonia (Pannonia Inferior) in the East.

- Gallia bellica. - Gallia Belgica, a former Roman province in present-day Belgium, Luxembourg and neighboring parts of France, Germany and the Netherlands. The indigenous population was Belgians, a mixture of Celts and Germans. 
- c(iuitas).Belgif - City of Belgis (in the Roman province Gallia Belgica).

- B(ri)ta(n)nia maior c(iuitates).lo(n)do(n)ia. Ca(n)tuar(ia). - United Kingdom, cities London [and] Canterbury. Canterbury is the center of Christianity in England, known for the Canterbury Cathedral from 597. It was the seat of the first Archbishop Augustine of Canterbury, who is considered the Apostle of England and the founder of the Church in England. Archbishop Thomas Beckett (1170) was killed and buried in the cathedral, which made the cathedral a place of pilgrimage for members of the Catholic Church and the Anglican community.

- Hyb(er)nia. c(iuitates).Dublinia.Armachuf. - Ireland, the cities of Dublin and Armagh (an important religious center of Ireland since Celtic times).

- Scocia ciuita $\int(a n) c(t) i$ Andree. - Scotland, the city of St. Andrews (St. Andrew, the ecclesiastical capital of Scotland).

- NorWegia. - Norway.

\section{Geographical list of areas and cities in Africa}

- Termini affrice -Ex parte orientis · Nilus A meridie zona torrida $\cdot$ A septe(n)t(ri) one ma[re] medit(er)raneu(m). Ab occide(n)te medit(er)ranei m[are] refluxio. $H(e c) h(a b e) t p(r o) v i(n)$ cias s(u)bscriptas. - Borders of Africa: East, Nile; in the south the tropic zone; in the north, the Mediterranean Sea; to the west, the Mediterranean Sea (Gibraltar Pass). It has the provinces listed below:

- In libia: C[iuitas] - Cirene - - In Libya the city of Cyrene. Cyrene was originally a Greek colony, known as the home of the poet Callimachus, the founder of the New Academy in Athens, Carneacles, the mathematician and geographer Eratosthenes, and the ancient writer Synesius, who associated Neoplatonic conceptions with Christian teaching. Cyrene is mentioned in the Bible in connection with the Jewish diaspora and in the New Testament in connection with Simon of Cyrene who carried the cross for Jesus (Matthew 27:32; Mark 15:21; Luke 23:26) and other preachers (Acts, 2:10, 6: 9; 11:19, 20).

- In zeugi q(ue) (est) [uera] affrica: C(iuitas) Kartago - - In the region of Zeugis which is [real] Africa: the city of Carthage, on the site of today's city of Tunisia.

- In Getulia: ...- In Getulia [illegible]. Getulia (Gaetulia) is an ancient area in north-west Africa, south of Mount Atlas, in the vicinity of the Roman province of Mauritania. 
- In Numidia: C(iuitas). Ippone - In Numidia: the city of [H]ippone, today's port city of Annaba in Algeria. Numidia is a Roman province in North Africa, and the city of Hippone is the birthplace of Saint Augustine.

- In Maur[ita]nia: C(iuitas).Cefarea. - In Mauritania: City of Caesarea. The eastern part of the Roman province of Mauritania was named Caesarea, after the capital of Julius Caesar, near the present-day city of Cherchell in Algeria.

- In Tingitan[ea?] [:?] [C(iuitas).?] Tingif - - In Tingitana (in the Maghreb area), the city of Tingis (today's Tangier in Morocco).

- In Ethiopia orienta[lis.] [C(iuitas).?] Saba. - In Eastern Ethiopia, the city of Saba.

- In Ethiopia occide(n)t[alis.] Gades.Iux(ta) q(uam) mo(ns) Athl[as] - In Western Ethiopia, Cadiz, near the Atlas Mountains. Here, the term Western Ethiopia refers to northwestern Africa.

- In Ethiopia ult(er)i[ore :] monftra fu[illegible] - In external Ethiopia: creatures [further illegible].

\section{Conclusion}

Medieval maps or mappae mundi, were used not only to present a geographical image of nature and people, but also to show the biblical world after God's act of Creation. A map of the real geographical world, and complementary images, illustrate medieval semi-mythical geography. The real geographical world is placed in the context of the belief in salvation and in the moral framework of the Christian imagination, emphasizing, for example, in the two maps of the world in the London Psalter, that the world is not only created but protected by God and perhaps even the body of God. Such maps had a primary function in devotional practice, but could also serve as an itinerary on pilgrimages and as an educational tool in religious studies and theology, aiding in memory and providing guidance on information on a variety of topics that could never be fully written on such a small paper.

The Psalter World Map and the Psalter List Map have textual and pictorial content, which allows them to have multiple functions, as works of art and as a reference guide for religious and secular texts. Text, image, and map function in such a way that they manage to convey information and yet remain ambiguous enough to allow for different interpretations. Succeeding in combining so many different areas of study on such a small 
paper, the psalter maps aimed to attract readers, inviting them to return to the geographical map again and again to reflect on the diversity and greatness of the world as God's creation. Today, the Psalter World Map attracts the attention of researchers who deal with the history of the expansion of the geographical horizon of man, or the history of the geographical knowledge of medieval people.

Acknowledgment: The paper is the result of research within the project of Geographical faculty of the University of Belgrade funded by the Ministry of Education, Science and Technological Development of the Republic of Serbia.

\section{References}

Anderson, A. R. (1932). Alexander's Gate, Gog and magog, and the Inclosed Nations. Cambridge, Mass.: Medieval Academy of America.

Bagrow, L. (1966). History of Cartography. Cambridge. Harvard University Press. Reprinted, with corrections, from the 1964 edition. Edited by R. A. Skelton. Pp. 312.

Barber, P. (1989). Visual Encyclopaedias: the Hereford and other Mappae Mundi. The Map Collector, Autumn 1989, No. 48, Figure on p. 5.

Barber, P. (2013). The World in Miniature (Psalter World Map). In: Barber, P., Barnes, K., Erskine, N. et all. Mapping Our World: Terra Incognita to Australia. Canberra, ACT: National Library of Australia. Pp. 256.

Brott, L. L. (2018). The Geography of Devotion in the British Library Map Psalter. Cartographica: The International Journal for Geographic Information and Geovisualization. Univerity of Toronto Press., V. 53, N. 3, pp. 211-224.

Büttner, O. F. (2004). Der illuminierte Psalter im Western' in The Illuminated Psalter: Studies in the Content, Purpose and Placement of its Images, ed. F. O. Büttner. Belgium: Brepols, p. 106.

Burke, P. (2016). Where Geography Came From. In: The Wiley Blackwell Companion to Human Geography (Agnew, J. A., Duncan, J. S.). Wiley Blackwell, pp. 11-22.

Chekin, L. S. (2006). Northern Eurasia in Medieval Cartography: Inventory, Text, Translation, and Commentary. (Terrarum Orbis, 4). Turnhout: Brepols. Pp. 498. 
Delumeau, J. (2000), History of Paradise: The Garden of Eden in Myth and Tradition, University of Illinois Press, pp. 1-288.

Destombes, M. (ed.), (1964). Mappaemondes, A.D. 1200-1500. Monumenta Cartographica vetustioris aevi, vol. I: Catalogue prépare par la Commission des Cartes Anciennes de L'Union Géographique Internationale, Amsterdam: N. Israel. Imago Mundi, vol. 1. Supplements, no. 4.

Deycks, F. (ed.), (1851). Ludolphus. De itinere Terrae Sanctae liber. Bibiliothek des Litterarischen Vereins 25. Stuttgart.

Джаксон, Т. Н., Коновалова И. Г., Подосинов, А. В., Фролов, А. А. (2017).

Северная Евразия в картографии античности и средних веков. "Аквилон“, Москва, 528 с.

Foys, M. and Heather, W. (eds.), (2018). Virtual mappaemundi. Schoenberg Institute of Manuscript Studies.

Gautier Dalché, P. P. (1988). La „Descriptio mappe mundi“ de Hugues de Saint-Victor, Paris: Études Augustiennes, 231 pages.

Harley, J. B. (1989). Historical geography and the cartographic illusion. Journal of Historical Geography, Volume 15, Issue 1 Pages 80-91. Published by Elsevier Ltd.

Klein, W. A. (2016). Cartographic Imaginings: Mapping Anglo-Scotish Existence in the Late Middle Ages. In: Studies iconography, vol. 37, Medieval Institute Publications Western Michigen University Kalamazoo. Pp. 3174.

La Porte, M. (2012). A Tale of Two Mappae Mundi: The Map Psalter and its MixedMedia Maps. A Thesis Presented to the University of Guelph Atrium. Ontario, Canada. Pp. 116.

Laurent, J. C. M. (ed.), (1864, 2. Auflage 1873). Peregrinationes medii aevi quatuor die vier bedeutendsten mittelalterlichen Pilgerberichte von Burchardus de Monte Sion, Ricoldus de Monte Crucis, Odoricus de Foro Julii und Wilbrandus de Oldenborg. Lepzig, pp. 19-94.

Ludolf von Sucham's Description of the Holy Land and of the way Thither. Written in the year A. D. 1350. Edited and translated by Aubrey Stewart. Cambridge Library Collection. Digitally printed version, 2013. Cambridge University Press. 
https://books.google.rs/books?id=Kb71AAAAQBAJ\&pg=PA66\&lpg=PA6 $6 \& \mathrm{dq}=$ alcayre+otherwise+called + memphis + or + babylon+in+egypt\&sou rce=bl\&ots

Mackinder, J. H. (1904). The Geographical Pivot of History. The Geographical Journal, Vol. 23, No. 4, pp. 421-437. Published by: The Royal Geographical Society (Wit the Institute of British Geographers). https://doi. org/10.2307/1775498.

Miller, K. (1895). Mappaemundi: Die ältesten Weltkarten. Heft III. Die kleineren Weltkarten. Stuttgart. Jos. Roth'sche Verlagshandlung, pp. 37-43.

Miller, K. (1896). Mappaemundi: Die ältesten Weltkarten. Heft V. Die Ebstorfkarte. Stuttgart: Jos. Roth'sche Verlagshandlung, pp. 1-79.

Muir, M. (2011). The Psalter Mappaemundi: Medieval Maps Enabling ascension of the soul within Cristian Devotional Practices. Bowling Green State University.

Morgan, N. (1988). A Survey of Manuscripts Illuminated in the British Isles, Vol. IV. Early Gothic Manuscripts (II) 1250-1285. London and Oxford: Harvey Milller and Oxford University Press, pp. 374+462 ills.

Орачев, А. (2005). България в европейските картографски представи до XIX век. „Борина“. София, 144 с.

Рајт, Д. К. (1988). Географические представления в епоху крестовых походов. „Наука“. Москва.

Rana, L. (2008). Geographical Thought - A Systematic Record of Evolution. Concept Publishing company. New Delhi.

Reudenbach, B. (1998). Die Londoner Psalterkarte und ihre Rückseite: Ökumenenkarten als Psalterillustration. Frühmittellalterliche Studien, vol. 32, Issue 1, pp.164-181.

Савић, А. (2015). „Измишљање“ Вавилона - Географија и хагиографија у блискоисточном итинерару Светог Саве Српског. Zbornik radova Vizantološkog instituta LII, Beograd, s. 1-22. DOI: 102298/ZRVI1552291S.

Schöller, B. (2014). Wissen speichern, Wissen ordnen, Wissen übertragen Schriftliche und bildliche Aufzeichnungen, der Welt im Umfeld der Londoner Psalterkarte. Zürich: Chronos Verlag, p. 304.

Соловјев, А. (1936). Застава Стефана Душана над Скопљем 1339. Гласник Скопског научног друштва. XV-XVI, 345-347.

Strickland, D. H. (2003). Saracens, Demons and Jews: Making Monsters in Medieval Art. Princeton, NJ: Princeton University Press. 
Šakaja, L. (2015). Uvod u kulturnu geografiju. Leykam international, Zagreb, s. 352.

Talbert, R. and Unger R. (ed.), (2008). Cartography in Antiquity and the Middle Ages Fresh Perspectives, New Methods. Brill, Leiden • Boston.

Thurston, H. P. (1898). Harper's Dictionary of Classical Antiquities. Harper \& Brother, New York.

Uhden, R. (1931). Zur Herkunft und Systematik der mittelalterlichen Weltkarten. Geographishe Zeitschrift, 37 (1931), p. 26.

Van Duzer, C. (2013). Hic sunt dracones: The Geography and Cartography of Monsters. In: Mittman, A. S. and Dendle, P. J. (edited by): The Ashgate Research Companion to Monsters and the Monstrous, 18.

Abingdon: Routledge Handbooks Online, 2017, acc. 12 feb. 2021. p. 50.

Van Duzer, C. (2019). The Psalter Map (c. 1262). In: Terkla D., Millea, N. (edited by): A Critical Companion to English Mappae Mundi of the Twelfth and Thirteenth Centuries. University of California Los Angeles. Woodbridge: The Boydell Press. Pp. 179-196.

Wacha, H. \& Brott L.L. (2020). Reframing the World: The Materiality of Two Mappaemundi in BL, Add. MS 28681, Imago Mundi, 72/2, pp. 148-162. DOI: $10.1080 / 03085694.2020 .1748374$

Wacha, H. and Levernier, J. (2019). Cartography and Code: Incorporating Automation in the Exploration of Medieval Mappaemundi. Digital Medievalist 12(1), 4, pp. 1-29. DOI: https://doi:org/10.16995/dm.84. Peerreviwed article in Digital Medievalist, a journal published by the Open Library of Humanities.

Whittington, K. (2004). Devotion, Space and Monstrosity in the Map Psalter. Undergraduate Thesis, Middlebury College.

Whittington, K. (2014). The Psalter Map: A Case Study in Forming a Cartographic Canon for Art History, Kunstlicht, January 2014, pp. 19-26.

Woodward, D. (1985). Reality, Symbolism, Time and Space in Medieval World Maps. Annals of the Association of American Geographers, Vol. 75, № 4, pp. 510-521. Published by: Taylor and Francis, Ltd.

Woodward, D. (1987). Medieval Mappaemundi. In: The History of Cartography. Vol. 1: Cartography in Prehistoric, Ancient and Medieval Europe and the Mediterranean. Edited by Harley, B. J. and Woodward ,D. Chicago: University of Chicago Press, 286-370. 
Brott L. L. and Wacha, H. The Psalter List Map British Library Additional MS 28681, f. 9v in Psalter List map (BL Add 28681, f. 9v) Description, Sources, and Bibliography https:/ / sims2.digitalmappa.org/36 (pristupljeno 27.01. 2021).

Mittman, A., Crossley, C., Wacha, H., Brott, L. Foys M. Psalter World Map (BL Add MS 28681, f. 9r). Digitalno izdanje srednjovekovnih karata, urednici Martin Foys, Heather Wacha et all: Philadelphia, PA: Schoneberg Institute of Manuscript Studies, 2018. Doi: 10.21231/ef21-ev82. https://sims2. digitalmappa.org/36 (pristupljeno 27.01.2021).

The Psalter List Map British Library Additional MS 28681, f. 9r.

The Psalter List Map British Library Additional MS 28681, f. 9v.

https://www.bl.uk/collection-items/psalter-world\# 